\title{
Backbenchers to the front: A case for political history from below?
}

\author{
STEPHEN WILKS
}

\author{
I always voted at my party's call, \\ And I never thought of thinking for myself at all. \\ I thought so little, they rewarded me \\ By making me the Ruler of the Queen's Navee!
}

Sir Joseph Porter KCB, gratefully reflecting in HMS Pinafore on his ultimately rewarding time spent on the backbench.

Wars have led to innumerable fine memoirs by foot soldiers. Less so Australian politics. Memoirs of note by backbenchers reflecting on their service in an Australian parliament are few. The journalist and military historian Max Hastings once wrote that he did not seek interviews with surviving military officers of very senior rank as due to their age the result was usually 'a conversational train running upon familiar railway lines'; the recollections of regimental and battalion commanders were of greater historical value. ${ }^{1}$ My own observations of published writings on government are that senior ministers and departmental secretaries are typically so weighed down by personal baggage that they often default to a reassuring account that invites only minimal reflection on the author's own record. Could those sitting quietly on the backbench (or even at a lonely desk in a government agency) have acquired a more cogent understanding of events, less weighed down by reputational self-interest?

I argue that the quality and openness of the observer matters more than their nominal position. Even if not the case, can a backbencher's story still be of inherent interest as a historical perspective on the life political? As effectively the foot soldier of parliamentary life, the daily chores of the humble backbencher are the raw material of politics. Life as a backbencher constitutes the entire parliamentary experience of most of our legislators. One reason they are little known as potential historical sources is simply that only a few of them have published memoirs of high quality. The two foremost exceptions are the main subjects of this review article. I write here mainly of published full-length memoirs by backbenchers who represented major parties in Australian parliaments, and so exclude Independents operating entirely on their own or in collaboration with a government that requires their support. Such

1 Max Hastings, The Korean War (London: Michael Joseph, 1987), xvii. 
circumstances mark them as a distinct category. Peter Andren, Cathy McGowan, Rob Oakeshott and Tony Windsor have produced memoirs, but tended to see themselves as Independents rather than backbenchers per se. ${ }^{2}$

One could well assume that backbenchers, as political practitioners, would not require great encouragement to talk about themselves. Yet Australian backbenchers have only occasionally gone the next step of taking to the pen or keyboard, and then locating a willing publisher. Those who have done so have usually been consigned to the secondary ranks of the publishing world in the form of academic or minor independent publishers, not to mention often self-publishing. Accounts by backbenchers in other parliamentary systems are hardly common but nor are they especially rare; examples from Westminster itself have been produced by the Conservative MP Sydney Chapman and the Labour member turned Tory insider Woodrow Wyatt. ${ }^{3}$ The British political scientist Peter G. Richards in 1972 perceived an 'added vigour of members' over the preceding decade, but in reaching this conclusion added that 'autobiographies and biographies about Members are of varied quality. ${ }^{4}$ Lack of knowledge of the bedrock layer of political life can lead to underestimation of the historical place of those seemingly mundane denizens of the chamber. As R. A. W. Rhodes wrote, 'the surprise is that mainstream political science should have had so little to say about the occupation of politician'.5

One reason for this is that some scholarly assessments of backbenchers have made little use of their personal experiences. A widely read and relatively early analysis was 'Democracy's Dodo' by Helen Nelson (note how the title is a conclusion in itself), included in the third iteration of the justly celebrated Australian Politics readers that she co-edited with Henry Mayer. ${ }^{6}$ This is a trenchant but aggregated summation of the apparently insurmountable constraints that she held to explain the lack of backbencher initiative. Backbenchers are presented as a near-uniform class that can appropriately be dealt with collectively, with little reference to individual experience. The entry is really about the functioning of parliament in the broad, not backbenchers themselves. Perhaps this was because there were so very few decent backbencher memoirs to be drawn upon in 1973. Seven years earlier, an account

2 Peter Andren, The Andren Report: An Independent Way in Australian Politics (Melbourne: Scribe, 2003); Cathy McGowan, Cathy Goes to Canberra: Doing Politics Differently (Clayton, Vic.: Monash University Publishing, 2020); Rob Oakeshott, The Independent Member for Lyne: A Memoir (Crows Nest, NSW: Allen \& Unwin, 2014); Tony Windsor, Windsor's Way (Carlton, Vic.: Melbourne University Press, 2016). I also exclude members of minor parties who produced memoirs, such as Don Chipp, Cheryl Kernot and Sid Spindler of the Australian Democrats.

3 Sydney Chapman, Back to the Drawing Board: Memoirs of a Back Bencher (Haverfordwest, UK: Absolute, 2010); Woodrow Wyatt, Confessions of an Optimist (London: Collins, 1985). Wyatt was briefly a junior minister under Clement Attlee.

4 Peter G. Richards, The Backbenchers (London: Faber and Faber, 1972), 9, 236.

5 R. A. W. Rhodes, 'Theory, Method and British Political Life History', Political Studies Review 10 (2012): 170 (original emphasis).

6 Helen Nelson, 'Democracy's Dodo', in Australian Politics: A Third Reader, ed. Henry Mayer and Helen Nelson (Melbourne: F. W. Cheshire, 1973), 558-69. 
in Current Affairs Bulletin by an unnamed 'Commonwealth backbencher' (reported by Nelson to be Harry Turner, the long-serving Liberal member for Bradfield) similarly emphasised the constraints facing backbenchers, but ended with a plea for establishing policy-oriented parliamentary committees as a basis for their playing a more constructive role in the legislative process. ${ }^{7}$

Even the more recent proliferation of prime ministerial memoirs usually treat backbenchership purely as a passing phase, ideally to be disposed of in a page or two at most. Malcolm Turnbull, the most recent such memoirist, does however provide a five-page chapter on his brief sojourn on the backbench, in which he records his disproval of expectations he would be a 'hopeless' local member, and reflects on his puzzlement at Peter Costello's public displeasure over an innocent but sincere effort to contribute to tax reform. ${ }^{8}$ Most other prime ministerial memoirs almost imply that doing time on the backbench was endured as an unavoidable necessity of limited inherent interest before commencing on an inexorably upwards career path.

The first book-length memoir by an Australian backbencher to attract widespread attention was the eponymous Andrew Jones M.H.R. by Himself, published in 1967 when the author held the federal seat of Adelaide. ${ }^{9}$ Jones had been elected in 1966 at the precocious age of 22 . He was nonetheless a strident social conservative who seemed out of kilter with much of the 1960s, cutting across the book's attempt to impart a 'regular guy' image (aided by cartoons from Paul Rigby portraying Jones as an amiable innocent). Much of the book is dedicated to countering its author's reputation for impetuosity and a much-publicised comment that many of his parliamentary colleagues seemed to have an alcohol problem; most of the remainder is more dedicated to extended self-reflection than to assessing the role of a backbencher. A Canberra Times reviewer thought that 'Andrew Jones' only redeeming point is his youth, but time, alas, will even take care of that'. ${ }^{10}$ He failed to be re-elected in 1969 .

That same year Edward St John produced A Time to Speak, surely the most anticipated of all Australian backbencher memoirs and, judging from press reports, the most widely read. ${ }^{11}$ Like Jones, St John's single term in parliament and book were dominated by reactions to his frank comments; in his case concerning the behaviour of Prime Minister John Gorton, and the investigation into the loss of HMAS Voyager. Unlike Jones, he saw himself as firmly on the Liberal Party's progressive wing. Another Canberra Times reviewer was only slightly less unimpressed, perceiving that St John 'presents himself in part as an Old Testament prophet, recalling us to

\footnotetext{
7 'Backbenchers', Current Affairs Bulletin 37, no. 11 (18 April 1966).

8 Malcolm Turnbull, A Bigger Picture (Melbourne: Hardie Grant, 2020), 121-25.

9 Andrew Jones, Andrew Jones M.H.R. by Himself (Adelaide: Rigby, 1967).

10 Alan Fitzgerald, 'Thoroughly Modern Andy', Canberra Times, 16 December 1967, 11.

11 Edward St John, A Time to Speak (Melbourne: Sun Books, 1969); on anticipated sales, see 'Mr St John Calls for Change', Canberra Times, 10 October 1969, 11.
} 
righteousness'. ${ }^{12}$ In 1976 Charles Russell produced Country Crisis. Russell was the Country Party member for the federal Queensland seat of Maranoa for one term in 1949-51, amid which he left the party to sit as an Independent. ${ }^{13}$ His book mostly provides advice on how to radically reshape the nation's economy.

Rather more durable backbench authors were the Labor MHRs Gil Duthie and Les Haylen. Duthie's book bears the arresting title I Had 50,000 Bosses: Memoirs of a Labor Backbencher 1946-1975, a reference to his electors in the central Tasmanian seat of Wilmot that he held from 1946 to $1975 .{ }^{14} \mathrm{He}$ duly noted Wilmot's importance as his electoral base, and contrasted 'the quainter rituals of Canberra and the strains, ambition and rivalry among colleagues' with 'basic work' in his electorate. ${ }^{15}$ Diary extracts illustrating the typical chores of a backbencher are essentially a short descriptive digression-helping a destitute family secure better public housing, attending monthly branch meetings, aiding constituents in navigating puzzling bureaucracies, and suchlike. Duthie also provided for the aspiring backbencher a handy checklist of 'main fields of operation'. Unsurprisingly, these are the electorate office, out visiting in the electorate, the parliament, and the party. ${ }^{16}$

These passages are but modest interludes amid Duthie's observations on bigger events. Despite the book's title, his electors mostly remain in the background. He reflected little on the role of the backbencher, nor did he dwell on celebrating it as a worthy station in life. His most compelling observation was to defend the party system as 'the answer to dictatorships', for a parliament of Independents 'would be unthinkable chaos' ${ }^{17} \mathrm{He}$ did, however, bring a backbencher's perspective to some bigger issues and events. Gough Whitlam as deputy leader of the Australian Labor Party (ALP) under Arthur Calwell appeared to be 'a taste of things to come' with 'a real capacity to minimise hostilities', but also a worrisome tendency to the odd 'split second of indiscipline'. ${ }^{18}$ Goings-on in the wider world elicited few insights beyond summations of local reactions, hence we are informed of the impact of the 1967 Six Day War on Tasmanian apple and pear growers. Duthie served on the ALP national executive, and his anguished account from this perspective of the 1955 split forms the core of his book. A notable contribution was his organisation of a rural committee within his electorate as a means for local farmers to advise the ALP, the first of its kind.

12 Geoffrey Sawer, "'The Word” From the Prophet in Exile', Canberra Times, 11 October 1969, 15.

13 Charles W. Russell, Country Crisis (Brisbane: W. R. Smith \& Paterson, 1976).

14 Gil Duthie, I Had 50,000 Bosses: Memoirs of a Labor Backbencher 1946-1975 (Sydney: Angus \& Robertson, 1984).

15 Duthie, I Had 50,000 Bosses, 192.

16 Duthie, I Had 50,000 Bosses, 338.

17 Duthie, I Had 50,000 Bosses, 341.

18 Duthie, I Had 50,000 Bosses, 191, 205. 
Haylen, by contrast, dwelt on the backbencher experience mainly to complain about it, but at least his book is more quotable than Duthie's more equable account. Hence there was 'nothing so desolate as the landscape of a dead issue and a lost cause', and whenever 'a weary Minister moved the "question be put" then 'the numbers rolled like tanks and we went home with the tracks of the juggernaut on our weary shoulders'. ${ }^{19}$ Otherwise he recounted a broadly similar story to Duthie's of victory in 1943 in the seemingly unwinnable seat of Parkes (in suburban Sydney, not the later rural seat in western New South Wales), and enduring much of the long Menzies era before losing Parkes in 1963. He was less hopeful than Duthie that Whitlam, 'the young brolga', would provide salvation for the ALP. ${ }^{20}$ Haylen's reflections on being a backbencher did not advance much beyond reiterations of his frustration. Anecdotes were deployed at the expense of coherent narrative, making his memoir an uneven slog.

Gordon Bryant was the federal Labor member for Wills in inner Melbourne from 1955 to 1980 (including serving as a minister under Whitlam), encompassing a policy-rich era during the 1960 s when Labor was in reconstruction. He published not a full-length memoir but rather an article that was included in the first of the Mayer readers, written when he was still firmly on the backbench. Although short, his account included an informative rendition of the backbencher's work routine. Bryant reported that in the Labor Party, the federal members are becoming in effect the Public Service of the Party' by serving on party policy committees and developing discussion papers, in retrospect a powerful unintended reflection on the subsequent decline of the bureaucracy's policy-advising role. ${ }^{21}$

Of the several other autobiographies and memoirs by individuals who served as a backbencher, few are mainly about their political service. In most, parliament was but an extended interlude in a longer, often much richer life, with the result that most do not add greatly to an understanding of the backbench experience. Henry 'Jo' Gullett wrote fluently about his varied life encompassing Oxford, journalism, the military, parliament and diplomacy, but his account of serving as a federal Liberal backbencher (1946-55) dwells mostly on impressions of the famous figures he encountered. ${ }^{22}$ Wylie Gibbs, surgeon turned federal Liberal member for Bowman (1963-69), described how an impromptu examination of Harold Holt raised doubts about the prime minister's physical fitness, which might have had a bearing his disappearance just days later. ${ }^{23}$ Bob Whan provided a succinct summary

19 Leslie Haylen, Twenty Years' Hard Labor (South Melbourne: Macmillan, 1969), 3.

20 Haylen, Twenty Years' Hard Labor, 177.

21 Gordon Bryant, 'The Work of a Federal Member', in Australian Politics: A Reader, ed. Henry Mayer, 2nd ed. (Melbourne: F. W. Cheshire, 1967), 419.

22 Jo Gullett, Good Company: Henry 'Jo' Gullett: Horseman, Soldier, Politician (St Lucia, Qld: University of Queensland Press, 1992).

23 Wylie Gibbs, Compassionate Steel: The Memoirs of Wylie Gibbs, Surgeon, Grazier and Federal Politician (West Geelong, Vic.: Barrallier Books, 2017). 
of the difficulties of political survival as Labor member for the federal rural swing seat of Eden-Monaro during the Whitlam years, with most of his time taken up by making himself available for personal interviews in all 42 communities in the electorate. ${ }^{24}$ Although Whan was wrong to doubt that such a demanding and insecure seat would ever produce a minister (Gary Nairn, Mike Kelly and Peter Hendy were to come, not to mention Whan's distant predecessors Austin Chapman and John Perkins), he otherwise wrote with a prescience suggestive of a strong feel for both politics and policy. The title of Peter Fisher's detailed memoir of holding the federal seat of Mallee for the Nationals from 1972 to 1993, Backbench, promises much, but contains more exhaustive detail than insight. ${ }^{25}$ Gordon Dean as Liberal member for the federal Queensland seat of Herbert (1977-83) winsomely reflected that 'although I had always thought of myself as innately shy and had to push myself to perform, when performing I enjoyed it'. ${ }^{26}$

Sometimes parliamentary experience features mainly as a backdrop to personal tragedy. Carolyn Hirsh, a Labor member of the Victorian Parliament, endured the suicide of a daughter, followed by bouts of alcoholism that led to Premier Steve Bracks demanding her resignation. ${ }^{27}$ Colin Caudell describes the accidental death of his then wife, but also provides a graphic account of the 1996 overthrow of South Australian Premier Dean Brown and his deputy, as witnessed in the party room. The scene 'resembled an act from a Shakespearean play, as the condemned men made their way to the political gallows. ${ }^{28}$

Among backbench senators, the most interesting account was provided by Nancy Buttfield, who became a Liberal senator from South Australia in 1955. ${ }^{29}$ She wrote, among much else, of being the being the first woman to drink at the formerly exclusively male Members' Bar in Parliament House (with encouragement from Robert Menzies, incidentally). Interestingly, she thought that 'many people failed to realise the power of the backbench to frustrate a Minister's Bill and ensure amendments before it went into the Chambers'. ${ }^{30}$ She was particularly surprised to find that even lobbyists rarely appreciated this.

Stephen Loosley, senator for New South Wales (1990-95), was a major figure in the New South Wales ALP, yet his account in his 2015 Machine Rules of how the party machine actually worked was far from incisive and raised more questions

\footnotetext{
24 Bob Whan, Chops for Breakfast: A Lucky Generation in an Age of Accelerating Change (Carss Park, NSW: published by the author, 2014).

25 Peter Fisher, Backbench: Behind the Headlines (Brisbane: CopyRight Publishing, 2011).

26 Gordon Dean, A Simple Country Lad: A Kind of Autobiography (West End, Qld: published by the author, 2007), 70 .

27 Carolyn Hirsh, Politics, Death and Addiction (Melbourne: Brolga, 2013).

28 Colin Caudell, Pick Myself Up \& Dust Myself Off(Coolum Beach, Qld: The Book Studio 2019), 78.

29 Nancy Buttfield, Dame Nancy: The Autobiography of Dame Nancy Buttfield (North Adelaide: published by the author, 1992), 106

30 Buttfield, Dame Nancy, 106.
} 
than it answered. ${ }^{31}$ Like Haylen's effort, Loosley's book relied on anecdote, but gained from drawing liberally on the breadth of his reading, proudly displayed in leading the reader through various political tales and ponderings. He spun suitably entertaining yarns about life in the ALP state headquarters in Sussex Street and 'the camaraderie of Senate life', but did not delve deeply into the joys and vicissitudes of the backbench. ${ }^{32}$ Loosely also exhibited a love for the ideal of public service and a pleasing preparedness to accept selected members of the opposing party as colleagues and even friends. Sam Dastyari, also once an ALP senator from New South Wales, provided in his 2017 One Halal of a Story a very personal account that is more about his family than politics, an example of Melbourne University Publishing's then openness to all sorts of writings by political figures. ${ }^{33}$ He depicted himself as constantly trying to rise above being a mere backbencher. A contemporaneous oddity is Jim Snow's Keating and His Party Room, effectively an extended survey of the Keating Government's policy record laced with accounts of caucus members lobbying ministers, authored by the backbencher who was chair of caucus (1993-96). ${ }^{34}$

That most of the books mentioned so far are, with some partial exceptions, superficial and lacking in stylistic distinction makes the next book I discuss all the more interesting.

That 'all politics is local' may seem to be something of a cliché. This sage advice is said to have been coined by Thomas 'Tip' O'Neill, one-time speaker of the United States House of Representatives, and is most often applied to the United States where local government is far stronger than in Australia. It becomes a deadly reality even in Australia if one happens to be the holder of a swing seat or, even worse, one usually held by another party. This definitely concentrates the political mind and, in one case, has given us a remarkable political memoir. A Hard Row to Hoe by Alan Stewart is a shining nugget not just among memoirs by backbenchers, but also amid the shelf loads of self-serving memoirs by prime ministers, would-be prime ministers, prime ministerial spouses and just plain ministers. ${ }^{35}$ It may well be unique in the Australian political memoir pantheon, for few if any other such works have so thoroughly and attractively documented the day-to-day reality of life-or, in Stewart's case, of temporary survival —as an honourable, hard-working and (mostly) humble backbencher.

31 Stephen Loosley, Machine Rules: A Political Primer (Carlton, Vic.: Melbourne University Press, 2015).

32 Stephen Loosley, Machine Rules, 43.

33 Sam Dastyari, One Halal of a Story (Carlton, Vic.: Melbourne University Press, 2017).

34 Jim Snow, Keating and His Party Room (North Melbourne: Australian Scholarly Publishing, 2017).

35 Alan Stewart, A Hard Row to Hoe: People and Politics in New South Wales (Kensington, NSW: New South Wales University Press, 1988). 
Stewart was the Labor member for the normally Liberal-held seat of Manly in the New South Wales Legislative Assembly from 1978 to 1984, courtesy of the 'Wranslides' of 1978 and $1981 .{ }^{36} \mathrm{He}$ set the tone of his memoir with an epigraph from Francis Bacon, recording wonderment that public figures harbour a desire 'to seek power over others and to lose power over a man's self'. Stewart recorded in detail an experience unique in his life, albeit with occasional less worthy digressions into score settling. He dwelt entirely on how a backbencher is forced to operate, in this case one spurred on and burdened by a combination of pride and knowledge that an early demise was near inevitable.

Stewart's title was drawn from a 1976 speech by Whitlam, forewarning of the difficulties facing a Labor candidate in the Manly area. It is common for Australian political memoirists to all too casually assert that their entry into politics was essentially accidental. This can induce wariness (and weariness) in seasoned readers of such tomes-assertions broadly along such lines as 'well, I never really wanted to, but I was practically forced to run for parliament; so please remember that I'm a regular guy (or girl) unlike all those others!' That Stewart does not labour unduly to project such a persona enhances his credibility as an observer. A Hard Row to Hoe opens with a vignette of his witnessing Neville Wran, not yet premier, addressing a crowd at Manly Beach. Stewart reflected that he had no inkling that this was a harbinger of his own future. He otherwise provided only a summary backstory about himself, recording that his working life began as a jackaroo and that later he was a field officer with the state ministry of agriculture. Campaigning for Whitlam in 1975 inspired his political interest, and when Manly came up he was undertaking a doctorate at Macquarie University concerning kangaroo interaction with livestock.

The ALP needed a candidate for Manly at the forthcoming state election of October 1978. Stewart was assured by the secretary of the local state electorate council that he had no chance of actually winning. He put himself down for 'an interesting experience', even if 'the ensuing defeat might be painful', effectively a confession that he was not entirely indifferent. ${ }^{37} \mathrm{He}$ duly told his family that he could not win, whereupon the adjacent seat of Earlwood, vacated by the former Liberal premier Eric Willis, fell to Labor at the ensuing by-election. Things started looking serious in Manly, and Stewart seemed to be acquiring the political contagion. He checked for campaigning tips from 'a young graduate in political science', one Steve Loosley, then already assistant general secretary of the New South Wales ALP. ${ }^{38}$ Stewart's science background was decidedly atypical among MPs from all parties, but a campaign photo was nonetheless contrived depicting him sporting a white lab coat

36 The Liberal Douglas Darby, who held the seat from 1945 to 1978, lost party preselection and stood successfully as an independent Liberal at the elections of 1962 and 1965; he was readmitted to the party in time for the election of 1968 .

37 Stewart, $A$ Hard Row to Hoe, 13.

38 Stewart, $A$ Hard Row to Hoe, 14. 
and seated by a microscope. (One wonders if this would be done today, when props used in candidate photos are usually a family with dog or a local football team.) A campaign visit by the Wran Government's attorney-general, Frank Walker, proved stimulating, not least as he told a wide-eyed Stewart that he was likely to win. They embarked on a flurry of drop-ins at local establishments, a 'whirlwind of smiling faces and outstretched hands' ${ }^{39}$ Stewart started to enjoy campaigning, guided also by some worldly-wise local ALP cadres, and went on to win comfortably.

Over the following five years and five months, his sense of wonderment changed in nature but never seems to have entirely faded, probably contributing to his eventually writing about his experiences. On election night, Stewart's reaction to winning was subdued, and he soon started working through some basic essentials: setting up an electorate office, hiring personal staff and having a one-on-one audience with the premier. He was warned by his new colleagues against accepting overtures to share a friendly drink with Rex Jackson, later jailed for taking bribes. The importance of party factions was very evident to Stewart, but he was unsure how to engage with them-the essential rules of life in the parliamentary Labor Party were unwritten but nonetheless seemed to be well understood by others. He soon appreciated that any challenge to authority within the party would not be readily forgotten, and noted the disconcerting readiness with which innocent gestures were interpreted as signalling which faction one would join; suspicion that he was of the Right derived in part from a religious picture spotted in his mother-in-law's house on election night. Factionalism seems no less strong in his day than now, with the Right acting to 'ruthlessly to crush any move which has not been the subject of a deal behind closed doors. ${ }^{40}$

Initially resistant, he found himself conforming to the sub-tribalism expected of a Labor MP by gravitating to the Left. He was also drawn into a continuing struggle for survival at the next election. Stewart appeared to lack a personal power base in the party, but as Manly was an unlikely a seat for Labor to hold, there was little danger of preselection challenges. Most of the next several years of his life was necessarily dominated by work in his electorate and the lobbying of ministers accordingly. He became absolutely determined to beat his irritatingly confident, smirking Liberal challenger for the forthcoming 1981 election, a former lord mayor of Sydney who Stewart referred to as 'the tooth fairy'. By comparison, his presence in the chamber of the Legislative Assembly seems minor; likewise in the caucus. Stewart displayed little reverence for parliament as an institution. At the opening of his first parliament, he experienced a surge of panic at 'how had I got mixed up with such a strange looking bunch?' 41 He was not greatly surprised to notice that few other members used the excellent parliamentary library.

39 Stewart, $A$ Hard Row to Hoe, 24.

40 Stewart, $A$ Hard Row to Hoe, 178.

41 Stewart, $A$ Hard Row to Hoe, 64. 
Wran was then at his peak and already almost legendary, but Stewart appears to have found him distant, verging on the Delphic. Cabinet minister Paul Landa, initially abrasive and perpetually impatient, gradually took a shine to Stewart and became an exacting guide. Stewart was bluntly counselled by senior figures like Landa that achievement derived from toeing the party's line, no matter how demeaning this seemed in the interim. He was pointedly tutored in such basic skills as how to politically manage a deputation seeking a minister's agreement (check in advance with his or her staff that the answer will be 'yes', and later take all credit arising from being seen to have made the minister acquiesce).

Stewart remained burdened by an underlying self-awareness of being a political outsider who was unlikely to last. Evidently preferring to have been a biologisthe continued work on his doctorate-his whole tenure in parliament was both a learning experience and an effort. Stewart was not exactly, as Richard Nixon famously said of himself, 'an introvert in an extrovert's profession', but nor was he a natural politician, and so sensibly remained open to advice from Landa and other wise souls. His ambivalence pushed him more towards reflectiveness than selfaggrandisement as a parliamentarian. But even he at one point acquired the itch of aspiring to be a minister, if only to have proven that he was 'as good as some of the party hacks'. ${ }^{42}$

Lengthy descriptions establish that Manly was an urban seat with an unusually strong sense of regional identity and host to some highly charged local issues. Stewart was drawn into a politically risky public debate held on the Manly Corso with his Liberal challenger on the vexed issue of managing the discharge of sewerage into waters off North Head. Both sides 'employed some effective tricks', but Stewart's effort to appear moderate and bipartisan did not prevent proceedings from approaching violence before a sudden downpour came to the rescue. ${ }^{43}$ For all his opponent's public polish, Stewart perceived 'some weakness behind the façade', notably a resort to bluster when denied the comfort of rehearsed lines. ${ }^{44} \mathrm{He}$ was disgusted on election eve during a ball organised by the local mayor to find his opponent's daughter paraded as lead flower girl for the guest of honour, Sir James Hardy. Narrowly re-elected, he felt 'forced into a tight mould'. ${ }^{45}$ A University of Sydney study later concluded that the ALP 'was lucky in the choice of the opposition candidate, a man who by contrast emphasized the strengths of their own candidate' of being unambiguously a local, and a member of a government that generously targeted Manly as a seat it wanted to retain. ${ }^{46}$ In his appealing honesty,

\footnotetext{
42 Stewart, $A$ Hard Row to Hoe, 159.

43 Stewart, $A$ Hard Row to Hoe, 130.

44 Stewart, $A$ Hard Row to Hoe, 139.

45 Stewart, A Hard Row to Hoe, 155.

46 Ernie Chaples, 'Manly', in Case Studies in New South Wales Electoral Politics, ed. Ernie Chaples and Helen Nelson (Department of Government and Public Administration, University of Sydney, 1985), 81.
} 
Stewart admitted that the largesse bestowed on Manly by the Wran Government encouraged 'a kind of cargo cult', with emergent problems greeted by 'whack-amole' responses. ${ }^{47}$

Tending to his electorate was usually more a necessity than a pleasure. Stewart stands out also for having captured the sheer banality of so much of political life. The public demanded the satisfaction of pet causes and the solving of personal problems. Constituent work generated the usual array of worthy cases, 'regulars' and decided oddities. The sinister owner of a local theatre who tried to warn Stewart off from investigating complaints about his noisy and alcohol-sodden establishment turned out to be the 'Woolworths Bomber', a failed extortionist. Stewart prudently declined an invitation to inspect the interior of a local brothel that could have been operating in contravention of state law.

Much of all this sounds — and is — unsurprising. Yet Stewart recounted his experiences with immediacy and vividness. The occasional humour he imparted is of the driest variety. For all his efforts in Manly, his vote rose and then fell with shifts in Wran's popularity. What he did not cover in his memoir is also significant. He showed little interest in parliamentary committees, otherwise a staple of backbenchers trying to attract attention and simulate the exercise of influence. There was also little interest in how government formulates or implements policy. The state's public service was simply a presence, portrayed merely as an occasional impediment to the delivery of largesse. Issues of accountability in government hardly mattered for the holder of so marginal a seat.

Stewart's career in Manly moved into a final phase when he visibly tired of local politics. A rumour that he had lost interest in retaining his seat seemed confirmed when he absented himself from a state party conference to visit Taronga Zoo, there to ponder the metaphoric implications of chimpanzee behaviour. He vowed to use what time he had left in parliament to look beyond his electorate to the wider issues, mainly environmental, that first drew him to politics. His efforts to make a policy difference did not involve statements in the chamber, nor the introduction of private member's bills, but rather appeals directly to ministers. The book ends abruptly yet strongly with Stewart, defeated soundly at the election of March 1984, declaring himself to have been mentally ready for 'other doors to find' ${ }^{48} \mathrm{He}$ did not express bitterness, other than noting that preoccupation with his electorate cost him his doctorate: his submitted thesis was rejected by its examiners as lacking sufficient research. (Later he completed a doctorate at Griffith University on environmental approval processes.)

47 Stewart, A Hard Row to Hoe, 139.

48 Stewart, A Hard Row to Hoe, 208. 
A Hard Row to Hoe stands out from other backbencher memoirs because of the care and vigour with which Stewart recounted the raw detail of his working life. This may well be unique in the Australian political memoir genre, making for a fine testament of politics at its most fundamental. Also, Stewart's electoral insecurity and the foreknowledge that he will eventually lose his seat helps give his book a sense of direction, at times almost of drama, with every act of his contributing (or otherwise) to his prospects for re-election. The inevitability of political extinction and the artificiality of political life helped to render him highly thoughtful. He remained a relative outsider to party politics, willing to bear sceptical witness to what to a machine man like Loosley must have seemed the natural order of things.

Such scepticism and lack of defensiveness also helps make Hard Row to Hoe a pleasing read. Stewart is a very competent stylist. Although more anecdotal than analytical, the anecdotes are assembled to add up to a rich picture. He also has the advantage of having written well before Australian political memoirs conformed to the formulaic cardboard style that is now standard. References to his family life fill out the picture of being a backbencher, but do not dominate.

Politics was much more central to the wider life of another Labor backbencher, the late Ken Fry, federal member for the Australian Capital Territory (ACT) seat of Fraser, 1974-84. Although his A Humble Backbencher presented his life in full, its core is his time in parliament. The title sounds to have been meant somewhat ironically, hinting at the greater issues that he nonetheless pursued. Pleasingly, he dedicated his memoir 'to all backbenchers, who also serve' ${ }^{49}$ Like Stewart, Fry wrote long after leaving politics, and not so as to promote a still unfolding career.

As Fry was strongly entrenched in his local community and ALP branch well before entering parliament, his memoir lacks the sense of ongoing discovery that animated Stewart's. He entered parliament at the age of 53, after long experience as a soldier, farmer and public servant. Unlike Stewart, Fry won a safe Labor seat. His main political battle was in securing preselection, defeating Peter Wilenski and Susan Ryan. Like Stewart, he had a sense of being an oddity among his political peers, but otherwise swam relatively happily in political currents. He dwelt more knowledgeably than Stewart on the Labor Party's entrenched factionalism, and recounted efforts by the New South Wales Right to exert power over the ACT branch. Fry attributed much of the Right's personal hostility to his having defeated it in two preselection battles (the other was in 1967 for the state seat of Bathurst, which he failed to win at the election of the following year).

Some of the interest in Fry's account lies in his holding an ACT seat before the advent of self-government, and so representing a constituency governed by the Commonwealth alone. Hence he faced an even wider range of demands from

49 Ken Fry, A Humble Backbencher: The Memoirs of Kenneth Lionel Fry (Canberra: Ginninderra Press, 2002). 
electors than did his parliamentary colleagues, extending from nature strips to international affairs. Both Fry and Stewart testified to the importance of engaging loyal and tolerant electorate assistants skilled in handling truculent electors and dealing effectively with the bureaucracy, though Stewart seems to have been more discriminating regarding pleas for assistance. Fry even personally guaranteed a small loan to an alcoholic constituent to stave off the repossession of her washing machine. By contrast, Bryant in the 1960s had markedly less access to personal staff and usually dealt directly with the public service himself. Joan Child, the first female Speaker of the House of Representatives and whose memoirs were published posthumously in 2015, appears to have positively enjoyed dealing with her electors in the suburban Melbourne seat of Henty. ${ }^{50}$

But Fry's great contribution were his reflections on how a backbencher can be effective beyond a local role. Holding a safe seat increased his latitude to pursue national and international issues that had little to do directly with most of his constituents, notably concerning the environment and, especially, East Timor (Timor-Leste). He had much in common with another member who also used a memoir to push some very particular views, the ardent free trader Bert Kelly (a junior minister for nigh on three years under Holt and Gorton but more usually an incorrigibly outspoken backbencher). ${ }^{51}$ The conclusion of Fry's book is that 'the role of a backbencher can be effective and satisfying', especially as they can 'make a positive contribution to the Parliamentary process by using avenues of communication both inside and outside the Parliament to develop and present alternative viewpoints and policies. ${ }^{52}$ This is especially so, he thought, when in Opposition, during which members experience greater freedom courtesy of less pressure from the frontbench than when in government, and have more opportunity to use committee work to help guide policy development in good time for the eventual return to office.

Most importantly, Stewart and Fry dwelt on the exact means by which they tried to step beyond their limitations as backbenchers and influence policy. Both showed that a backbencher with focus and determination can do much. In some instances they needed to be prepared to risk their seat. Stewart was well aware that protecting the rainforests of his state's north-east, 'the single issue that could justify my political career', was far removed from Manly yet still found himself in a late-night meeting lobbying Wran on their importance. ${ }^{53}$ As the only biologist in the parliamentary party, he was abruptly directed to effectively lead a crucial visit by MPs to the threatened Terania Creek forest, an outcome of Deputy Premier Jack Ferguson's having more gently and effectively persuaded Wran. Fry described how he sought to build positive personal relationships with ministers responsible for his own

50 Joan Child, with Graeme Johnstone, Joan Child of Labor (Cromer, Vic.: Graeme Johnstone, 2015).

51 C.R. ('Bert') Kelly, One More Nail (Adelaide: Brolga Books, 1978).

52 Fry, A Humble Backbencher, 162.

53 Stewart, $A$ Hard Row to Hoe, 204. 
areas of policy interest and so, for example, targeted John Dawkins as minister for finance on ending the tax deductibility of land clearances. On international issues, Fry found that he could use his status as an MP to exercise influence beyond the parliament through excursions into his own brand of diplomacy, including lobbying foreign governments and giving activists access to fellow MPs. He listed other backbenchers who were also active outside the parliament on respective favoured issues, including Kelly on free trade, Alan Missen on human rights and Neville Bonner on Indigenous affairs. (Fry, incidentally, also finished a PhD—in Australian history at The Australian National University after having left parliament.)

Neither Stewart nor Fry appear to have been deeply moved by causes anchored in their electorate. Yet Stewart remains the standout for using his memoir to provide such a convincingly fulsome account of what it was actually like, how it felt, to be a backbench MP, with only a late and productive diversion into a bigger issue. He offered few reflections on government beyond his own direct experiences: his story was essentially a simple one of being a political foot soldier.

Stewart and Fry demonstrate how potentially valuable further backbencher memoirs might be. Barring many sitting unpublished in archives, they are not so much untapped historical sources as ones that need to be created in the first place. Their foremost potential importance is in providing a record of political and parliamentary experience. Anyone writing on a political life is likely to benefit from a sense of the gritty daily reality that their subject must have endured early in their career, an essential stepping stone to whatever exceptional achievements came later. To be aware of the initial individual experience of politics-whether delight, trepidation, uncertainty, or even a sense of entrapment-can help enliven an otherwise idealised account.

A second potential benefit is to provide a better historical sense of how backbenchers have tried to exert policy influence, and so of what place they occupy among the wider array of such forces. The backbencher memoir, should it ever reach the critical mass needed to constitute a genre, could be a basis for collectively helping to reassess the role of the backbencher in determining policy, not openly in the chamber but by activity undertaken less visibly in the proverbial corridors of power. Stewart's attraction to the rainforests intensified as his interest in local affairs dimmed; Fry stepped far outside conventional parliamentary politics in pursuing his interest in international issues. Both authors, along with Buttfield, produced accounts that seem very broadly consistent with the much later findings of Brenton Prosser and Richard Denniss concerning the influence of 'marginal members' ${ }^{54}$ Their study placed more emphasis on minor party crossbenchers and Independents than on

54 Brenton Prosser and Richard Denniss, Minority Policy: Rethinking Governance When Parliament Matters (Carlton, Vic.: Melbourne University Press, 2015). 
backbenchers from the major parties, and did not refer to the memoirs of Stewart or Fry. They did, however, interview some major party members, who each spoke of exercising influence via the party room, committees and private members' bills. ${ }^{55}$

The best political memoirs are by those who are simultaneously thoughtful, free of an urge to defend a major policy record, and devoid of any plan to return to politics-individuals like Stewart and Fry. Mainstream publishers are probably reluctant to take backbenchers on as authors, for most lack the celebrity heft needed to make them a ready commercial proposition. Is there a special role here for academic publishers? Publishers and historians alike, let us consider that someone does not always have to have been at the top of the tree to play the role of seer effectively. Never underestimate the potential power of subordinates as observers, and even as rarely appreciated influencers.

55 These were John Langmore, Judith Troeth and Ron Boswell. Troeth and Boswell did, however, serve as parliamentary secretaries, and Boswell was also leader of the Nationals in the Senate and a shadow minister. None of the three was ever a minister. 
This text is taken from Australian Journal of Biography and History: No. 5, 2021, published 2021 by ANU Press, The Australian National University, Canberra, Australia.

doi.org/10.22459/AJBH.05.2021.09 